\title{
The Effect of Green Synthesized CuO Nanoparticles on Callogenesis and Regeneration of Oryza sativa L.
}

\author{
Sadaf Anwaar ${ }^{1}$, Qaisar Maqbool ${ }^{2,3 *}$, Nyla Jabeen ${ }^{1 *}$, Mudassar Nazar ${ }^{2}$, Fazal Abbas ${ }^{3,4}$, \\ Bushra Nawaz ${ }^{5}$, Talib Hussain ${ }^{6}$ and Syed Z. Hussain ${ }^{7}$ \\ ${ }^{1}$ Department of Biotechnology and Bioinformatics, International Islamic University Islamabad, Islamabad, Pakistan, \\ ${ }^{2}$ Department of Biotechnology, Virtual University of Pakistan, Lahore, Pakistan, ${ }^{3}$ Interdisciplinary Research Organization, \\ University of Chakwal, Chakwal, Pakistan, ${ }^{4}$ Department of Physics, International Islamic University Islamabad, Islamabad, \\ Pakistan, ${ }^{5}$ Department of Mechatronics, University of Engineering and Technology Taxila, Chakwal, Pakistan, ${ }^{6}$ National \\ Institute of Vacuum Science and Technology, Islamabad, Pakistan, ${ }^{7}$ Department of Biological Sciences, Quaid-i-Azam \\ University, Islamabad, Pakistan
}

OPEN ACCESS

Edited by:

Agnieszka Ludwików Adam Mickiewicz University in Poznañ, Poland

Reviewed by:

Taras P. Pasternak,

Institute of Biology II, Germany

Tariq Jan,

International Islamic University,

Pakistan

Ishaq Ahmad,

National Centre for Physics, Pakistan

*Correspondence:

Qaisar Maqboo qaisar.vu@gmail.com

Nyla Jabeen

nyla.iiui@gmail.com

nyla.jabeen@iiu.edu.pk

Specialty section: This article was submitted to

Plant Biotechnology, a section of the journal

Frontiers in Plant Science

Received: 30 June 2016 Accepted: 18 August 2016 Published: 31 August 2016

Citation:

Anwaar S, Maqbool Q, Jabeen N, Nazar M, Abbas F, Nawaz B, Hussain T and Hussain SZ (2016) The Effect of Green Synthesized CuO Nanoparticles on Callogenesis and Regeneration of Oryza sativa L.

Front. Plant Sci. 7:1330. doi: $10.3389 /$ fpls.2016.01330
In this study, we have investigated the effect of copper oxide nanoparticles (CuO-NPs) on callogenesis and regeneration of Oryza sativa L (Super Basmati, Basmati 2000, Basmati 370, and Basmati 385). In this regard, CuO-NPs have been bio-synthesized via Azadirachta indica leaf extract. Scanning electron microscope (SEM) analysis depicts average particle size of $40 \pm 5 \mathrm{~nm}$ with highly homogenous and spherical morphology. X-ray diffraction (XRD) and Fourier transform infrared spectroscopy (FTIR) have been employed to confirm the phase purity of the synthesized NPs. It is found that CuO-NPs exhibit very promising results against callus induction. It is attributed to the fact that green synthesized CuO-NPs at optimum dosage possess very supportive effects on plant growth parameters. In contrast to callogenesis, differential regeneration pattern has been observed against all of the examined O. sativa L. indigenous verities. Overall observation concludes that $\mathrm{CuO}$, being one of the essential plant nutrients, has greatly tailored the nutritive properties at nano-scale.

Keywords: copper oxide nanoparticles, SEM, XRD, FTIR, callus induction, regeneration

\section{INTRODUCTION}

Plant tissue culture is of prime importance due to its novel and versatile applications in basic and advanced biotechnological research. In commercial point of view, it not only provides genetically modified plants but also responsible for the mass propagation of plants with desired characteristics (Mahna et al., 2013). In plant tissue culture aseptic condition is one of the basic requirement. Microbial contamination in tissue cultured plants is one of the major hurdle which leads to the massive loss of platelets. In plant tissue culture, several reports of silver (Abdi et al., 2008) and titanium oxide (Shiraishi et al., 2009) NPs as antimicrobial agents have been reported.

Callus induction and shoot regeneration are important in cell and tissue culture techniques for plant improvement (Kumar et al., 2009). A valuable export commodity of Pakistan is "Basmati rice." Many environmental constrains limit its production. In order to meet food requirement worldwide, it is a big need to improve the existing germplasm of Basmati cultivars (Naqvi et al., 2005). Applications of in vitro transfer techniques to plant improvement depend on regeneration capacity (Higuchi and Maeda, 1990). Callus cultures are particularly significant in plant biotechnology. 
Management of the auxin to cytokinin ratio in the medium can be directed to the development of shoots, roots and somatic embryos from which whole plant can subsequently be produced (Tariq et al., 2008).

In modern material sciences, research on nanoparticles (NPs) is one of the most attractive and active areas of research. NPs have wide applications due to their size, structure, and physiochemical properties in industries and agriculture (Safavi, 2014). There are several methods reported for the fabrication of metallic NPs, plants seem to be the best choice, and NPs produced by plants are more stable, least toxic and biocompatible (Iravani, 2011). Toxic effects of NPs for plants and animals have been reported but there is no report till now documented which showed the harmful effects of NPs on tissue culture plants (Zafar et al., 2016). Among all reported NPs so far, CuONPs being a significant kind of metal oxide NPs, are widely used in catalysis, biomedical applications, gas sensors, solar energy conversion, high-temperature superconductors, and field emission emitters with unique features and higher efficiency (Yin et al., 2005). Conventionally, $\mathrm{Cu}$ in its bulk form is vastly utilized as nutritive plant medium in callus induction and regeneration but lesser specific surface area and lower surface energy limit its reactivity.

Keeping in view, we have followed a facile green synthesis route for $\mathrm{CuO}-\mathrm{NPs}$ fabrication and its callogenesis and regeneration effects have been examined against important recalcitrant O. sativa L. cultivars (Basmati 2000, Basmati 385, Basmati 370, and Super Basmati). So far, to the best of our knowledge, no or very few reports are available in literature for bio-synthesis mediated callogenesis and regeneration effect of CuO-NPs against O. sativa $\mathrm{L}$. or any other cultivars. The aim of this study is to elaborate and understand the least toxic and nutritive effects of photo-synthesized $\mathrm{CuO}-\mathrm{NPs}$ in callus induction and regeneration of O. sativa $\mathrm{L}$. It is strongly believed that this work would open new corridors in the field of tissue culture technology.

\section{EXPERIMENTAL PROCEDURES}

\section{Green Synthesis of CuO NPs through $A$. indica Leaf Extract}

Authenticated A. indica leaves were collected from National Agricultural Research Centre (NARC), Pakistan. For purified extract, $20 \mathrm{~g}$ of dried plant leaves were finely grinded and added in $200 \mathrm{~mL}$ of deionized $\mathrm{H}_{2} \mathrm{O}$. This mixture were then placed in shaking incubator for $2.5 \mathrm{~h}$ at $40^{\circ} \mathrm{C}$ at $50 \mathrm{rpm}$ and later on was filtered using Whatman No. 1 filter paper. $7.98 \mathrm{~g}$ of $\mathrm{Cu}\left(\mathrm{CO}_{2} \mathrm{CH}_{3}\right)_{2} \cdot \mathrm{H}_{2} \mathrm{O}$ (Sigma-Aldrich) was added in $200 \mathrm{~mL}$ of the leaf extract and put at Scilogex Magnetic Stirrer attuned to $55^{\circ}$ Cat $\sim 1500 \mathrm{rpm}$ for $\sim 2.5 \mathrm{~h}$. Thereafter, mixture was collected and repeatedly loaded in GR BioTek centrifuge at $\sim 10,000 \mathrm{rpm}$ for $10 \mathrm{~min}$, brown pellets were isolated during concentration and collected. To remove uncoordinated compounds, washing with deionized water was done thrice. $\mathrm{CuO}-\mathrm{NPs}$ collected was dried using Memmert Hot Air Oven at $60^{\circ} \mathrm{C}$ for $\sim 5 \mathrm{~h}$ and further calcinations at high temperature was operated in Gallenkamp Furnace at $400^{\circ} \mathrm{C}$ for $\sim 2.5 \mathrm{~h}$.

\section{Characterization of Biosynthesized CuO-NPs}

To observe CuO-NPs morphology, SEM analysis was performed using JOEL_JSM_6490LASEM operating at $20 \mathrm{kV}$ coupled with Energy Dispersive X-ray (EDX) spectroscopy. SEM analysis was carried out by Gold coating CuO-NPs. Crystallographic studies of photosynthesized $\mathrm{CuO}-\mathrm{NPs}$ was achieved using $\mathrm{Cu} \mathrm{K} \alpha$ radiation ( $\lambda$ (Wavelength $)=1.54060 \AA$ ) with nickel monochromator in the range of $2 \theta$ between $20^{\circ}$ and $80^{\circ}$ with step size $0.2^{\circ}$. Scherrer's formula (Equation 1) is employed to calculate average crystallite size. Moreover, FT-IR spectroscopy of CuO-NPs were carried out using $\mathrm{KBr}$ pellet technique (SHIMADZU_FT-IR) wave number ranging $400-4000 \mathrm{~cm}^{-1}$.

\section{Collection of Plant Material}

Four seed varieties of rice (Oryza sativa L.) were obtained from NARC (National Agriculture Research Centre) including Super Basmati, Basmati 2000, Basmati 370, and Basmati 385. The explants were dehusked and surface sterilized with $70 \%$ Ethanol. N6 was used as basal medium with 3\% Sucrose and $8 \mathrm{~g} / \mathrm{L}$ Gelrite Agar and $\mathrm{pH}$ was adjusted to 5.8 and autoclaved at $121^{\circ} \mathrm{C}$ for $20 \mathrm{~min}$ at 15 psi. After autoclaving the media, CuO-NPs were also added at various $\mathrm{mg} / \mathrm{L}$ concentrations. To avoid cluster formation of NPs at the base, the medium was allowed to cool up to $45^{\circ} \mathrm{C}$ and after this the flasks were kept at $4^{\circ} \mathrm{C}$ till the media solidified.

\section{Callus Induction}

For callus induction N6 (Songstad et al., 1991) media ( $2 \mathrm{mg} / \mathrm{L}$ of 2,4-D) was used and supplemented with CuO-NPs (1-20 mg/L) and without $\mathrm{CuO}-\mathrm{NPs}$ as control. The culture tubes were kept in both dark as well as light ( $16 / 8 \mathrm{~h}$ photoperiod) conditions at $25 \pm 2{ }^{\circ} \mathrm{C}$ for 12 days. After the specific incubation period of 10-13 days, embryogenic-calli induced from seed scutellum were obtained. Callus induction frequency was obtained by following formula:

$$
\begin{aligned}
& \text { Callus induction frequency (\%) } \\
& \qquad=\frac{\text { No. of calli produced by seeds }}{\text { No. of seeds inoculated }} \times 100
\end{aligned}
$$

\section{Regeneration of Callus}

The embryogenic-calli produced were transferred on three different regeneration media with different concentrations and combinations of hormones supplemented with $\mathrm{CuO}$-NPS and without $\mathrm{CuO}-\mathrm{NPs}$ as control were tested for best regeneration media combination. After 8-10 weeks regeneration frequency was recorded using the formula given below:

$$
\begin{aligned}
& \text { Plant regeneration frequency }(\%) \\
& \qquad=\frac{\text { No. of calli regenerated into plantlets }}{\text { No. of calli inoculated for regeneration }} \times 100
\end{aligned}
$$




\section{Statistical Analysis}

Statistical analysis of the data was performed by two factorial Analysis of variance (Statistix 8.1 software). Each experiment was replicated thrice and each replication has 50 observations.

\section{RESULTS}

\section{Characterization of Prepared CuO-NPs}

From the SEM analysis, as shown in Figure 1, it is revealed that $\mathrm{CuO}-\mathrm{NPs}$ synthesized through green chemistry are highly homogenous and spherical in shape having mean particle size of $40 \pm 5 \mathrm{~nm}$. EDX pattern in Figure 2 explores us elemental percentage (i.e., by mass $65.33 \% \mathrm{Cu}$ and $34.67 \%$ O) of biosynthesized $\mathrm{CuO}-\mathrm{NPs}$. EDX results confirmed that only $\mathrm{Cu}$ and $\mathrm{O}$ ions are present in the synthesized NPs with the same ratio proportion as defined at the time of experiment.

In order to investigate the phase purity and average crystallite size of the synthesized sample, XRD technique has been utilized. Figure 3 illustrating crystallographic studies of biosynthesized $\mathrm{CuO}-\mathrm{NPs}$ in the $2 \theta$ ranges from $20^{\circ}$ to $80^{\circ}$ with step size $0.2^{\circ}$. Several prominent Bragg peaks, (110), (111), (-202), (202), $(-113),(-311)$, and (113) are observed in the XRD pattern. Micro structural crystallite size is calculated using Debye Scherrer formula (Equation 1).

$$
(t=0.89 \lambda / \beta \cos \theta)
$$

Where $t$ is the crystallite size, $\lambda$ is the wavelength of incident $\mathrm{Cu}$ $\mathrm{K} \alpha \mathrm{x}$-rays and $\beta$ is the full width at half maximum, in radians,
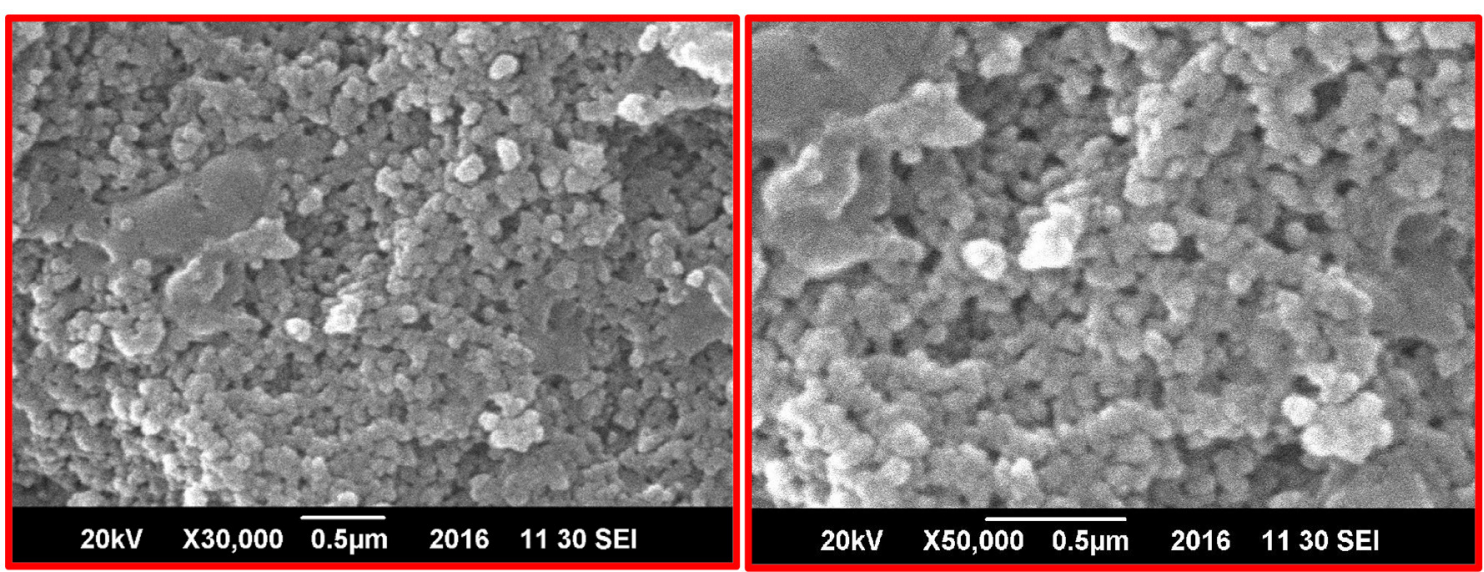

FIGURE 1 | SEM images of green fabricated CuO-NPs.

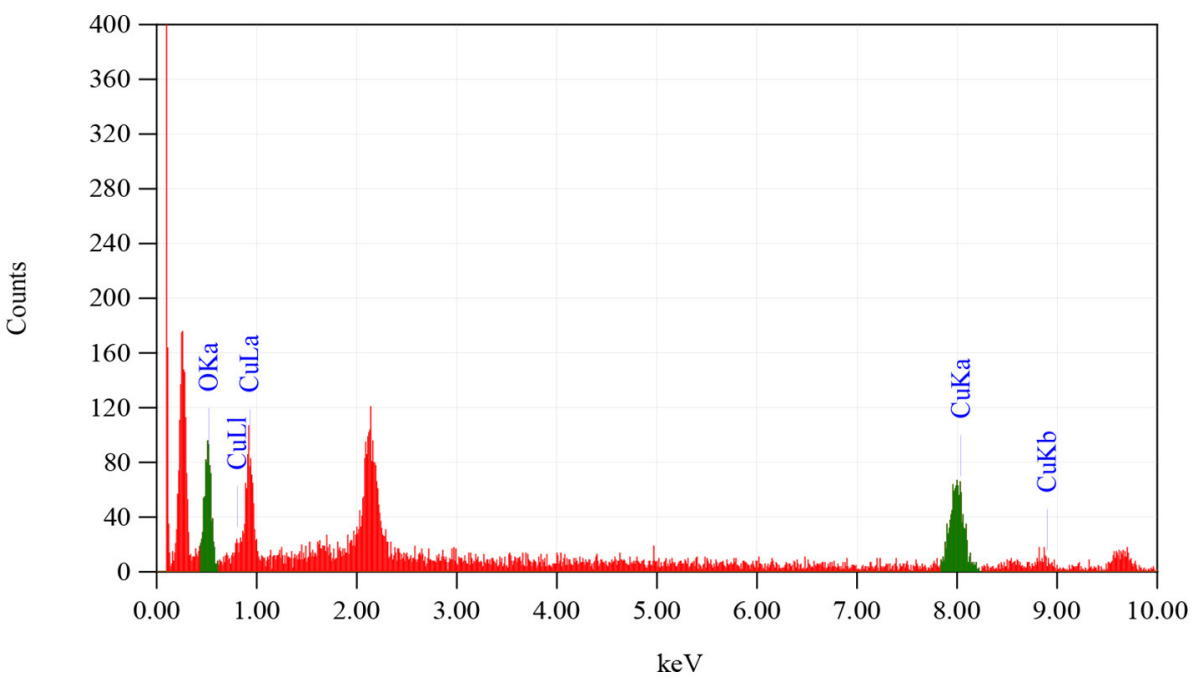

FIGURE 2 | EDX analysis of CuO-NPs. 
of the selected peak (111) at diffraction angle $\theta$. It has been calibrated that average crystallite size is closer to $7 \mathrm{~nm}$.

Utilizing non-destructive technique (FTIR spectroscopy) to probe the structural confirmation of molecules present inside the prepared sample, it is found that FTIR spectrum (Figure 4) exhibited $\mathrm{Cu}-\mathrm{O}$ specified peaks in the range from 590 to $675 \mathrm{~cm}^{-1}$. Moreover, $\mathrm{OH}^{-}$and $\mathrm{C}-\mathrm{O}$ stretching vibrations can be seen from 2800 to $4000 \mathrm{~cm}^{-1}$.

\section{Effect of Different Concentrations of CuO NPs on N6 Medium for Frequency of Callus Induction}

Results of different concentrations of CuO-NPs on callogenesis of four Pakistani rice cultivars are documented in Table 1. Results showed that seeds explants significantly responded to the addition of CuO-NPs in the medium. Figure 5 shows response of different concentrations on CuO-NPs on all the tested cultivars. With the increase in concentrations of NPs the callus induction frequency increased but only up to a certain concentration of
$10 \mathrm{mg} / \mathrm{L}$. All the four tested rice cultivars showed best response of callus induction at $10 \mathrm{mg} / \mathrm{L}$. Super Basmati showed best callus induction frequency of $94 \%$ on $10 \mathrm{mg} / \mathrm{L}$ of CuO-NPs followed by Basmati 385 (90\%), Basmati 370 (86\%), and Basmati 2000 (74\%). On increasing the concentration of CuO-NPs to $15 \mathrm{mg} / \mathrm{L}$ decrease in callus induction frequency is observed. Least callus induction frequencies were recorded on higher concentration $(15-20 \mathrm{mg} / \mathrm{L})$ of $\mathrm{CuO}-\mathrm{NPs}$ with $(38 \%)$ of Basmati 385 on $20 \mathrm{mg} / \mathrm{mL}$. The callus induction frequency is retarded on $20 \mathrm{mg} / \mathrm{L}$ as compared to the control.

\section{Regeneration of Callus with Different Concentrations of CuO-NPs on Selected Regeneration Media}

After the induction of calli the tested rice cultivars are shifted to regeneration media (NAA $1.0 \mathrm{mg} / \mathrm{L}+\mathrm{BAP} 0.5 \mathrm{mg} / \mathrm{L}+$ Kin $0.5 \mathrm{mg} / \mathrm{L}$ ) with various concentrations of $\mathrm{CuO}-\mathrm{NPs}$ and compared with control. After shifting of calli to regeneration media green spots were formed in few days (Figure 6). The

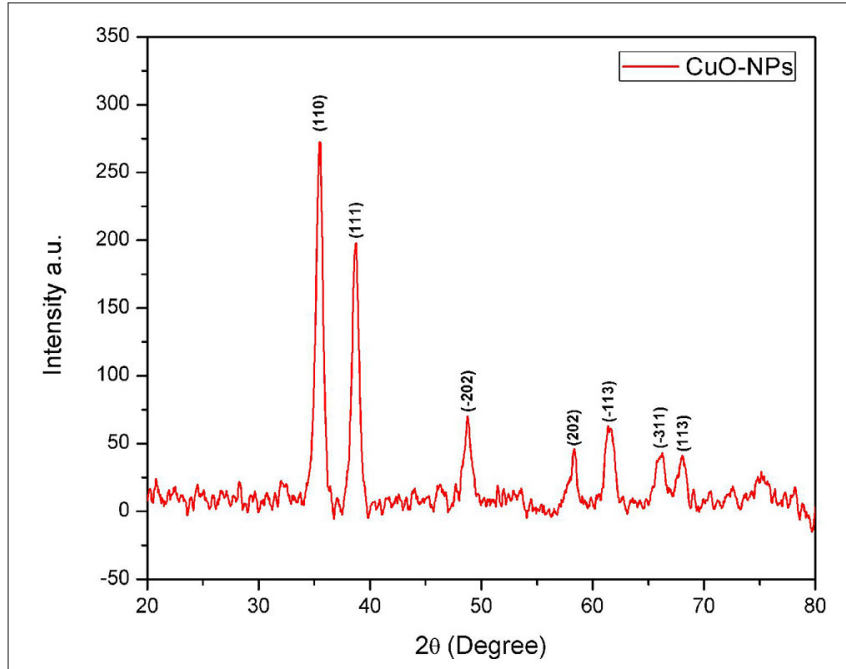

FIGURE 3 | XRD spectrum of CuO-NPs.

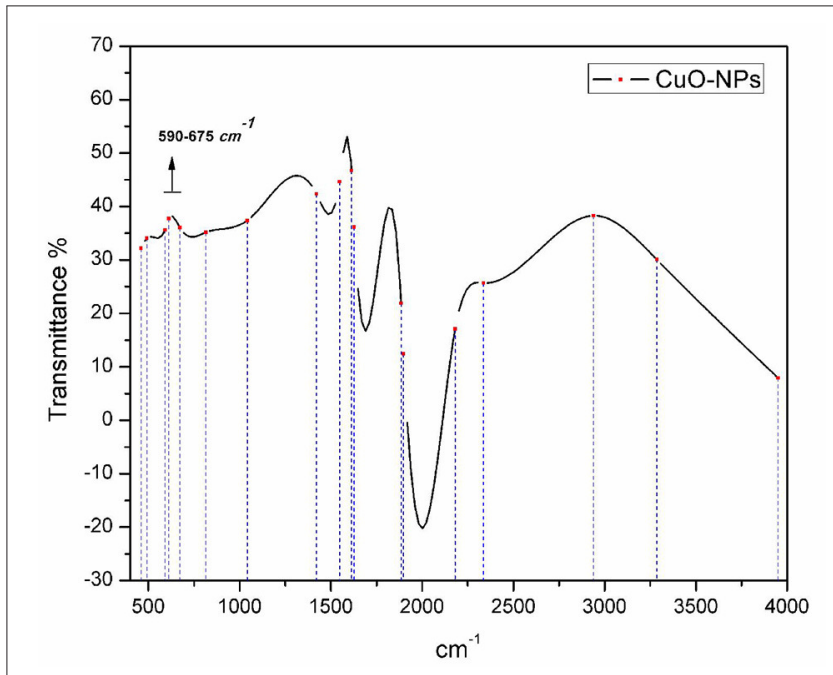

FIGURE 4 | FTIR spectrum analysis of bio-fabricated CuO-NPs.

TABLE 1 | Effect of different concentration of CuO-NPs on N6 medium for frequency of callus induction.

\begin{tabular}{|c|c|c|c|c|c|c|}
\hline O. sativa L. varieties & Control & $\begin{array}{r}\text { CuO-NPs } \\
(1 \mathrm{mg} / \mathrm{L})\end{array}$ & $\begin{array}{r}\text { CuO-NPs } \\
(5 \mathrm{mg} / \mathrm{L})\end{array}$ & $\begin{array}{l}\text { CuO-NPs } \\
(10 \mathrm{mg} / \mathrm{L})\end{array}$ & $\begin{array}{l}\text { CuO-NPs } \\
\text { (15 mg/L) }\end{array}$ & $\begin{array}{l}\text { CuO-NPs } \\
(20 \mathrm{mg} / \mathrm{L})\end{array}$ \\
\hline Basmati 2000 & $\begin{array}{c}27.00 \pm 1.1 \mathrm{~b} \\
(46 \%)\end{array}$ & $\begin{array}{c}34.00 \pm 1.3 e \\
(68 \%)\end{array}$ & $\begin{array}{c}24.00 \pm 2.9 b \\
(48 \%)\end{array}$ & $\begin{array}{c}39.00 \pm 2.7 b \\
(78 \%)\end{array}$ & $\begin{array}{c}23.00 \pm 4.7 a \\
(54 \%)\end{array}$ & $\begin{array}{c}21.00 \pm 1.1 \mathrm{a} \\
(42 \%)\end{array}$ \\
\hline Basmati 370 & $\begin{array}{c}21.00 \pm 3.3 a \\
(42 \%)\end{array}$ & $\begin{array}{c}37.00 \pm 3.1 \mathrm{e} \\
(74 \%)\end{array}$ & $\begin{array}{c}26.00 \pm 2.4 b \\
(52 \%)\end{array}$ & $\begin{array}{c}43.00 \pm 3.9 d \\
(86 \%)\end{array}$ & $\begin{array}{c}22.00 \pm 3.7 a \\
(44 \%)\end{array}$ & $\begin{array}{c}19.00 \pm 1.3 \mathrm{a} \\
(38 \%)\end{array}$ \\
\hline Super Basmati & $\begin{array}{c}29.00 \pm 2.2 d \\
(58 \%)\end{array}$ & $\begin{array}{c}46.00 \pm 2.2 f \\
(92 \%)\end{array}$ & $\begin{array}{c}33.00 \pm 4.1 c \\
(66 \%)\end{array}$ & $\begin{array}{c}47.00 \pm 1.4 d \\
(94 \%)\end{array}$ & $\begin{array}{c}35.00 \pm 1.1 d \\
(70 \%)\end{array}$ & $\begin{array}{c}27.00 \pm 2.8 \mathrm{~d} \\
(54 \%)\end{array}$ \\
\hline
\end{tabular}

Alphabets $(a, b, c, d, e, f)$ on values represents $L S D$ at $p<0.05$. 

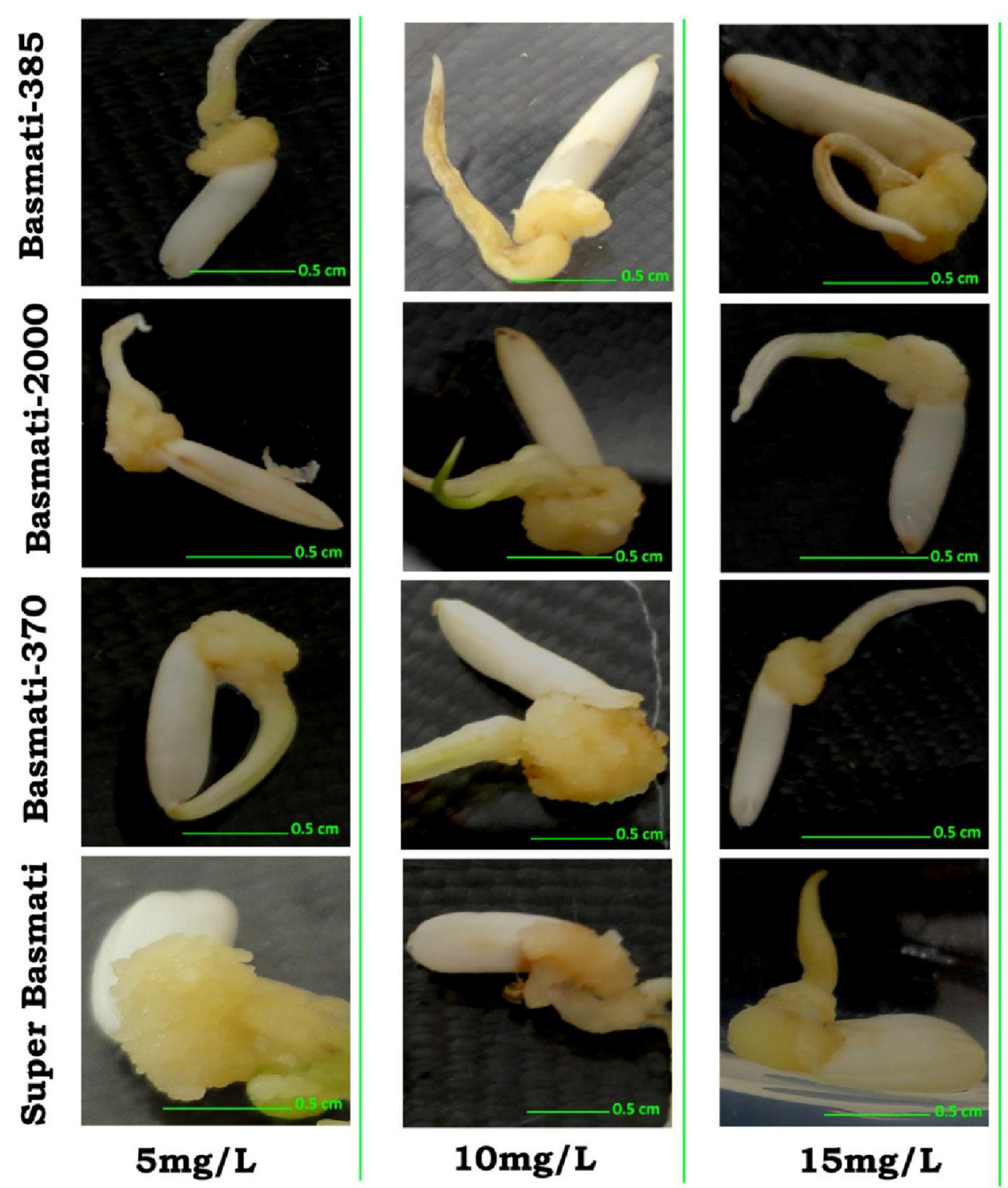

FIGURE 5 | Effect of CuO-NPs $(5,10$, and $15 \mathrm{mg} / \mathrm{L})$ in callogenesis of O. sativa L. (indeginous verities = Basmati 385, Basmati 2000, Basmati 370 , and Super Basmati).

green spots were sub-cultured routinely to fresh media. The regeneration potential of all the rice cultivars were enhanced by the addition of CuO-NPs as compared to control and are presented in Table 2. In contrast to callogenesis the regeneration was best observed in Basmati 385 (92\%) at higher concentration of $20 \mathrm{mg} / \mathrm{L}$ followed by Basmati 2000 (80\%), Super Basmati (52\%), and Basmati 370 (32\%). Basmati 370 showed poor regeneration at lower $\mathrm{CuO}-\mathrm{NPs}$ concentration as depicted in Figure 7. On supplementation of media with NPs concentration above $10 \mathrm{mg} / \mathrm{L}$ improved the organogenesis frequency. At $15 \mathrm{mg} / \mathrm{L}$ (37\%) regeneration was reported as compared to control (20\%) while best results were obtained on $20 \mathrm{mg} / \mathrm{L}$ of NPs for Basmati 370 as compared to control.

\section{DISCUSSION}

\section{Characterization Analysis of CuO-NPs}

Homogenous spherical morphology of the synthesized NPs using SEM clearly hints the successful capping action of bio-active molecules from $A$. indica plant extract. All the peaks in XRD pattern are well indexed according to JCPDS Card No. 05-0661 which confirms the formation of single phase cubic fluorite structure. No peaks related to any impurity like $\mathrm{Cu}, \mathrm{Cu}_{2} \mathrm{O}$ etc. is found. Stretching and vibrational mode of molecular structures in FTIR spectrum also provide sufficient data to investigate pure phase of prepared $\mathrm{CuO}-\mathrm{NPs}$ sample. $\mathrm{Cu}-\mathrm{O}$ exhibits its typical identification value on FTIR spectrum (Figure 4) confirming 


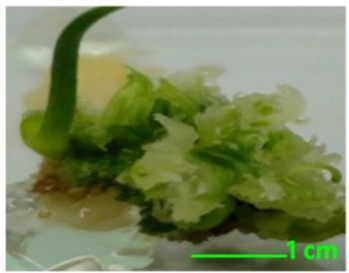

Basmati-385

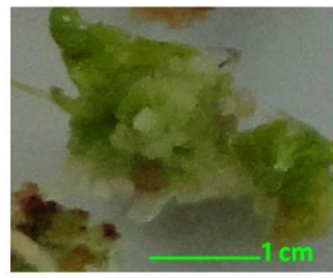

Basmati-2000

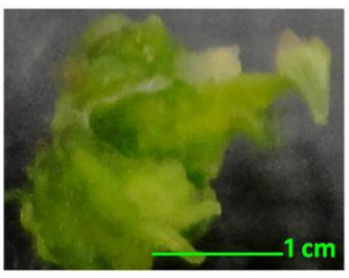

Super Basmati

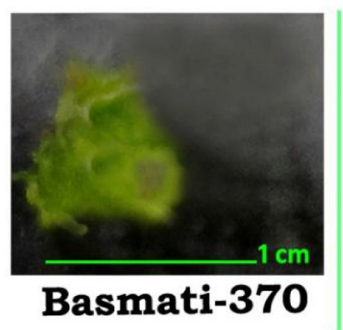

Basmati-370

FIGURE 6 | Formation of green spot in O. sativa L. (Basmati 385, Basmati 2000, Super Basmati, and Basmati 370 ) calli after transferring to regeneration media.

TABLE 2 | Effect of CuO-NPs on regeneration frequency.

\begin{tabular}{|c|c|c|c|c|c|c|}
\hline O. sativa L. varieties & Control & $\begin{array}{l}\text { CuO-NPs } \\
\text { (1 mg/L) }\end{array}$ & $\begin{array}{l}\text { CuO-NPs } \\
\text { (5 mg/L) }\end{array}$ & $\begin{array}{l}\text { CuO-NPs } \\
\text { (10 mg/L) }\end{array}$ & $\begin{array}{l}\text { CuO-NPs } \\
\text { (15 mg/L) }\end{array}$ & $\begin{array}{l}\text { CuO-NPs } \\
\text { (20 mg/L) }\end{array}$ \\
\hline Basmati 2000 & $\begin{array}{c}17.00 \pm 1.1 \mathrm{c} \\
(42 \%)\end{array}$ & $\begin{array}{c}27.00 \pm 2.1 d \\
(67 \%)\end{array}$ & $\begin{array}{c}21.00 \pm 3 c \\
(52 \%)\end{array}$ & $\begin{array}{c}16.21 \pm 1.1 b \\
(40 \%)\end{array}$ & $\begin{array}{c}27.00 \pm 1.1 \\
(67 \%)\end{array}$ & $\begin{array}{c}32.33 \pm 2.3 e \\
(80 \%)\end{array}$ \\
\hline Basmati 370 & $\begin{array}{c}8.00 \pm 1.3 a \\
(20 \%)\end{array}$ & $\begin{array}{c}0.00 \pm 0.00 \\
(0 \%)\end{array}$ & $\begin{array}{c}0.0000 \pm 0 \\
(0 \%)\end{array}$ & $\begin{array}{c}13.00 \pm 2.3 b \\
(32 \%)\end{array}$ & $\begin{array}{c}15.00 \pm 1.0 \\
(37 \%)\end{array}$ & $\begin{array}{c}17.00 \pm 3.1 \mathrm{c} \\
(42 \%)\end{array}$ \\
\hline Basmati 385 & $\begin{array}{c}24.00 \pm 1.00 d \\
(60 \%)\end{array}$ & $\begin{array}{c}33.67 \pm 1.7 e \\
(82 \%)\end{array}$ & $\begin{array}{c}23.00 \pm 1.4 d \\
(57 \%)\end{array}$ & $\begin{array}{c}19.00 \pm 2.1 \mathrm{c} \\
(47 \%)\end{array}$ & $\begin{array}{c}24.00 \pm 2.2 \\
(60 \%)\end{array}$ & $\begin{array}{c}37.34 \pm 1.0 \mathrm{e} \\
(92 \%)\end{array}$ \\
\hline Super Basmati & $\begin{array}{c}15.33 \pm 1.00 \mathrm{c} \\
(37 \%)\end{array}$ & $\begin{array}{c}19.00 \pm 2.2 c \\
(47 \%)\end{array}$ & $\begin{array}{c}11.00 \pm 1.4 b \\
(27 \%)\end{array}$ & $\begin{array}{c}9.00 \pm 2.8 \mathrm{a} \\
(22 \%)\end{array}$ & $\begin{array}{c}26.00 \pm 1.1 d \\
(65 \%)\end{array}$ & $\begin{array}{c}21.00 \pm 1.5 \mathrm{c} \\
(52 \%)\end{array}$ \\
\hline
\end{tabular}

Alphabets $(a, b, c, d, e)$ on values represents $L S D$ at $p<0.05$.

purely monoclinic morphology (Jan et al., 2014). Similarity in the specific spectrum of CuO-NPs spectrum was also observed previously (ThekkaePadil and Černík, 2013). Results from FTIR confirms XRD findings and clearly indicates formation of $\mathrm{CuO}$ NPs via plant extract having pure phase structure.

\section{Study of CuO-NPs Effect on Callogenesis}

The success of plant biotechnology depends on several factors which comprise an efficient tissue culture system for regeneration of plants from cultured cells and tissues (Khalafalla et al., 2010). Due to monoclinic structure, $\mathrm{CuO}-\mathrm{NPs}$ have antimicrobial and antioxidant properties reported (Sivaraj et al., 2014). Present study revealed concentration dependent positive influence of $\mathrm{CuO}-\mathrm{NPs}$ on callus induction in all the four tested cultivars. The best suited NPs concentration was recorded on $10 \mathrm{mg} / \mathrm{L}$ on N6 media supplemented with $2 \mathrm{mg} / \mathrm{L} \mathrm{2,4-D.} \mathrm{The} \mathrm{positive}$ effects of CuO-NPs on callus induction can be explain as copper is an essential nutrient in plants growth and act as a cofactor in many metallo-proteins and it also acts as structural element in regulatory proteins and involve in important physiological processes like electron transport chain, hormone signaling and cell wall metabolism (Yruela, 2005). With the increase in concentration the decrease in callogenesis was recorded, this could be best explain by the fact that high concentrations of $\mathrm{NPs}$ prove toxic for living system as release of $\mathrm{Cu}$ ions from $\mathrm{CuO}-\mathrm{NP}$ induce oxidative stress by catalyzing the formation of
$(\mathrm{OH})$ radicals from non-enzymatic chemical reaction between superoxide and $\mathrm{H}_{2} \mathrm{O}_{2}$ which is proved toxic for living system (Cheloni et al., 2016). At cellular level Copper toxicity is due to the binding of $\mathrm{Cu}$ ions to sulfhydryl groups in proteins this in turn inhibit enzyme activity (Van Assche and Clijsters, 1990). Copper ions are readily release from $\mathrm{CuO}-\mathrm{NP}$ and are highly impermeable to plasma membrane thus cause deficiency of other essential nutrients (Meharg, 1994).

\section{Regeneration of Callus with Different Concentrations of CuO-NPs}

The calli derived from all of the four tested cultivars were transferred to regeneration media control and with different concentrations of CuO-NPs to accesses the effects of NPs on regeneration potential. In contrast to calli induction with green spot formation, organogenesis was best reported on RM with $20 \mathrm{mg} / \mathrm{L} \mathrm{CuO-NPs}$ as they interacted with plants and cause morphological and physiological changes (Khodakovskaya et al., 2013). The positive or negative effects of NPs primarily depends upon composition, size, and concentration (Ma et al., 2010). With the increase in concentration from 1 to $20 \mathrm{mg} / \mathrm{L}$ significant enhanced organogenesis was observed. Similar results with increase in concentrations of $\mathrm{ZnO}$ NPs increase shoot regeneration in banana plant was reported by Helaly et al. (2014). The improvement in regeneration with the addition of CuO-NPs can be explained through both mechanisms as 

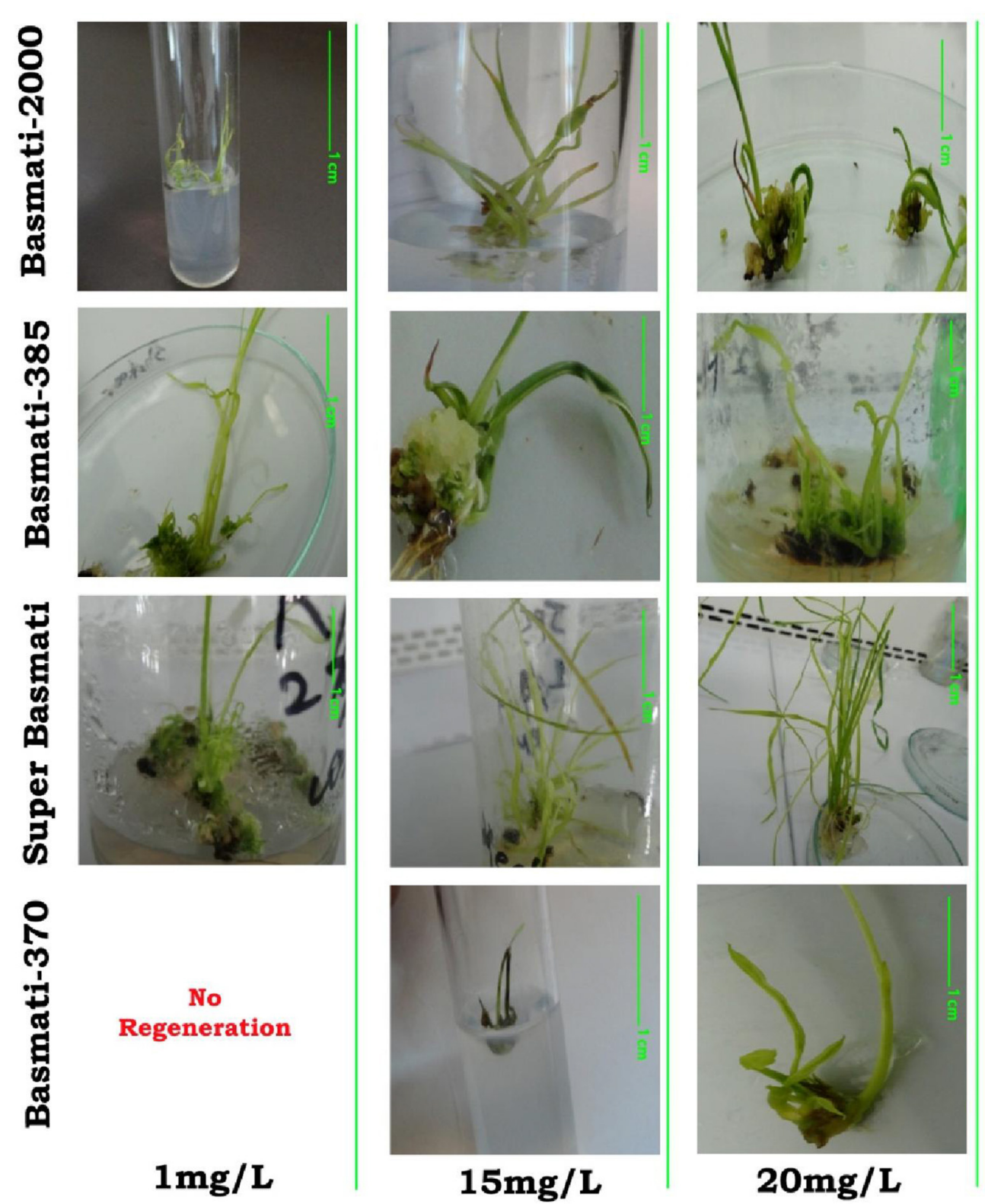

\section{$1 \mathrm{mg} / \mathrm{L}$}

$15 \mathrm{mg} / \mathrm{L}$

FIGURE 7 | Behavior of bio-synthesized CuO-NPs (1, 15, and $20 \mathrm{mg} / \mathrm{L}$ ) in organogenesis of $\mathrm{O}$. sativa L. (indeginous verities = Basmati 2000, Basmati 385, Super Basmati, and Basmati 370).

$\mathrm{Cu}$ an essential nutrient in plants growth and effects many physiological processes positively. Cu triggers some enzymes in plants which are involved in lignin synthesis and it is vital in several enzyme systems. It is also required in the process of photosynthesis, is essential in plant respiration and assists in plant metabolism of carbohydrates and proteins. $\mathrm{Cu}$ helps to promote the production and creation of seeds (Alaoui-Sossé et al., 2004). Other mechanism through which NPs can improve regeneration is by increasing the total proline contents in cell. Joshi et al. (2011) reported that NPs induce stress conditions which in turn cause increased proline contents. Proline is a biochemical marker, produced in cultured cells, during stress, and high concentration can save the plants' cells from getting into unfavorable conditions.

It was mainly observed that NPs addition increase enzyme activity like peroxidase, catalase, and nitrate reductase activity which also favors regeneration through effecting important physiological and biochemical processes (Husen and Siddiqi, 2014). Moreover regenerated plantlets treated with different concentrations of NPs reported better chlorophyll a/b ratio. This ratio indicates the activeness of PS-I and PS-II defining the overall rate of photosynthesis as more photosynthesis will 
lead to more regeneration (Parida and Das, 2005). Enhancement of chlorophyll pigments by the supplementation of $\mathrm{TiO}_{2}$ was also reported by Zheng et al. (2005). CuO-NPs can be toxic at higher concentration as $\mathrm{Cu}$ is amongst the indispensable elements in maintaining homeostasis in living system so can cause genotoxicity so supplementation of $\mathrm{CuO}-\mathrm{NPs}$ in tissue culture should not accede physiological tolerance range (Chang et al., 2012).

\section{CONCLUSION}

Green chemistry is proved to be most reliable, eco-friendly and preferably biocompatible technique to synthesized extremely fine size CuO-NPs. Due to small size of $40 \pm 5 \mathrm{~nm}$ with large surface area, effect of NPs on callus induction frequency concludes positive nutritive effect up to the concentration of $10 \mathrm{mg} / \mathrm{L}$. We

\section{REFERENCES}

Abdi, G., Salehi, H., and Khosh-Khui, M. (2008). Nano silver: a novel nanomaterial for removal of bacterial contaminants in valerian (Valeriana officinalis L.) tissue culture. Acta Physiol. Plant. 30, 709-714. doi: 10.1007/s11738-00 8-0169-z

Alaoui-Sossé, B., Genet, P., Vinit-Dunand, F., Toussaint, M. L., Epron, D., and Badot, P. M. (2004). Effect of copper on growth in cucumber plants (Cucumissativus) and its relationships with carbohydrate accumulation and changes in ion contents. Plant Sci. 166, 1213-1218. doi: 10.1016/j.plantsci.2003.12.032

Assche, F. V., and Clijsters, H. (1990). Effects of metals on enzyme activity in plants. Plant Cell Environ. 13, 195-206. doi: 10.1111/j.1365-3040.1990.tb0 1304.x

Chang, Y. N., Zhang, M., Xia, L., Zhang, J., and Xing, G. (2012). The toxic effects and mechanisms of $\mathrm{CuO}$ and $\mathrm{ZnO}$ nanoparticles. Materials 5, 2850-2871. doi: 10.3390/ma5122850

Cheloni, G., Marti, E., and Slaveykova, V. I. (2016). Interactive effects of copper oxide nanoparticles and light to green alga Chlamydomonas reinhardtii. Aquat. Toxicol. 170, 120-128. doi: 10.1016/j.aquatox.2015.11.018

Helaly, M. N., El-Metwally, M. A., El-Hoseiny, H., Omar, S. A., and ElSheery, N. I. (2014). Effect of nanoparticles on biological contamination of in vitro cultures and organogenic regeneration of banana. Aust. J. Crop Sci. 8, 612-624.

Higuchi, N., and Maeda, E. (1990). Enhanced plant regeneration in rice callus cultures following abscisic acid treatment. Jpn. J. Crop. Sci. 59, 359-368. doi: $10.1626 /$ jcs.59.359

Husen, A., and Siddiqi, K. S. (2014). Phytosynthesis of nanoparticles: concept, controversy and application. Nanoscale Res. Lett. 9, 1-24. doi: 10.1186/1556276X-9-229

Iravani, S. (2011). Green synthesis of metal nanoparticles using plants. Green Chem. 13, 2638-2650. doi: 10.1039/clgc15386b

Jan, T., Iqbal, J., Mansoor, Q., Ismail, M., Naqvi, M. S. H., Gul, A., et al. (2014). Synthesis, physical properties and antibacterial activity of Ce doped $\mathrm{CuO}$ : a novel nanomaterial. J. Phys. D Appl. Phys. 47:355301. doi: 10.1088/00223727/47/35/355301

Joshi, R., Shukla, A., and Sairam, R. K. (2011). In vitro screening of rice genotypes for drought tolerance using polyethylene glycol. Acta Physiol. Plant. 33, 2209-2217. doi: 10.1007/s11738-011-0760-6

Khalafalla, M. M., Elaleem, K. G. A., and Modawi, R. S. (2010). Callus formation and organogenesis of potato (Solanum tuberosum L.) cultivar Almera. J. Phytol. 2, 40-46.

Khodakovskaya, M. V., Kim, B. S., Kim, J. N., Alimohammadi, M., Dervishi, E., Mustafa, T., et al. (2013). Carbon nanotubes as plant growth regulators: effects on tomato growth, reproductive system, and soil microbial community. Small 9, 115-123. doi: 10.1002/smll.201201225 have experimentally proved that indigenous rice verity Super Basmati (O. sativa L.) shows maximum callogenesis response of 94\%.In contrast to callus induction the organogenesis was best observed in Basmati 385 (O. sativa L.) of 92\%.Due to strong antimicrobial behavior of CuO-NPs (Ren et al., 2009), it can also be an ideal candidate in plant tissue culture to ensure the environment aseptic. Keeping in view the importance of $\mathrm{CuO}$ NPs as vital nutritive agent for normal plants growth, as along with its cytotoxic behavior, an optimized concentrations of $\mathrm{CuO}$ NPs can be very beneficial in in vitro propagation of plants in future.

\section{AUTHOR CONTRIBUTIONS}

All authors listed, have made considerable, direct and intellectual contribution to the work, and approved it for publication.

Kumar, V., Parvatam, G., and Ravishankar, G. A. (2009). AgNO3: a potential regulator of ethylene activity and plant growth modulator. Electron. J. Biotechnol. 12, 8-9. doi: 10.2225/vol12-issue2-fulltext-1

Ma, X., Geiser-Lee, J., Deng, Y., and Kolmakov, A. (2010). Interactions between engineered nanoparticles (ENPs) and plants: phytotoxicity, uptake and accumulation. Scie. Total Environ. 408, 3053-3061. doi: 10.1016/j.scitotenv.2010.03.031

Mahna, N., Vahed, S. Z., and Khani, S. (2013). Plant in vitro culture goes nano: nanosilver-mediated decontamination of ex vitro explants. J. Nanomed. Nanotechnol. 4:161. doi: 10.4172/2157-7439.1000161

Meharg, A. A. (1994). Integrated tolerance mechanisms: constitutive and adaptive plant responses to elevated metal concentrations in the environment. Plant Cell Environ. 17, 989-993. doi: 10.1111/j.1365-3040.1994.tb02032.x

Naqvi, S. S., Sultana, R., and Rasheed, H. (2005). Tissue culture studies in Oryza sativa L. cvs. Basmati 385 and Super Basmati. Pak. J. Bot. 37, 823-828.

Parida, A. K., and Das, A. B. (2005). Salt tolerance and salinity effects on plants: a review. Ecotoxicol. Environ. Saf. 60, 324-349. doi: 10.1016/j.ecoenv.2004.06.010

Ren, G., Hu, D., Cheng, E. W., Vargas-Reus, M. A., Reip, P., and Allaker, R. P. (2009). Characterisation of copper oxide nanoparticles for antimicrobial applications. Int. J. Antimicrob. Agents 33, 587-590. doi: 10.1016/j.ijantimicag.2008.12.004

Safavi, K. (2014). Effect of titanium dioxide nanoparticles in plant tissue culture media for enhance resistance to bacterial activity. Bull. Environ. Pharmacol. Life Sci. 3, 163-166.

Shiraishi, K., Koseki, H., Tsurumoto, T., Baba, K., Naito, M., Nakayama, K., et al. (2009). Antibacterial metal implant with a $\mathrm{TiO}_{2}$-conferred photocatalytic bactericidal effect against Staphylococcus aureus. Surf. Interface Anal. 41, 17-22. doi: 10.1002/sia.2965

Sivaraj, R., Rahman, P. K., Rajiv, P., Salam, H. A., and Venckatesh, R. (2014). Biogenic copper oxide nanoparticles synthesis using Tabernaemontana divaricate leaf extract and its antibacterial activity against urinary tract pathogen. Spectrochim. Acta A 133, 178-181. doi: 10.1016/j.saa.2014. 05.048

Songstad, D. D., Armstrong, C. L., and Petersen, W. L. (1991). AgNO 3 increases type II callus production from immature embryos of maize inbred B73 and its derivatives. Plant Cell Rep. 9, 699-702. doi: 10.1007/BF00235361

Tariq, M., Ali, G., Hadi, F., Ahmad, S., Ali, N., and Shah, A. A. (2008). Callus induction and in vitro plant regeneration of rice (Oryza sativa L.) under various conditions. Pak. J. Biol. Sci. 11, 255-259. doi: 10.3923/pjbs.2008. 255.259

ThekkaePadil, V. V., and Černík, M. (2013). Green synthesis of copper oxide nanoparticles using gum karaya as a biotemplate and their antibacterial application. Int. J. Nanomed. 8, 889. doi: 10.2147/IJN.S40599

Yin, M., Wu, C. K., Lou, Y., Burda, C., Koberstein, J. T., Zhu, Y., et al. (2005). Copper oxide nanocrystals. J. Am. Chem. Soc. 127, 9506-9511. doi: $10.1021 / \mathrm{ja0} 05006 \mathrm{u}$ 
Yruela, I. (2005). Copper in plants. Braz. J. Plant Physiol. 17, 145-156. doi: 10.1590/S1677-04202005000100012

Zafar, H., Ali, A., Ali, J. S., Haq, I. U., and Zia, M. (2016). Effect of ZnO nanoparticles on Brassica nigra seedlings and stem explants: growth dynamics and antioxidative response. Front. Plant Sci. 7:535. doi: 10.3389/fpls.2016.00535

Zheng, L., Hong, F., Lu, S., and Liu, C. (2005). Effect of nano- $\mathrm{TiO}_{2}$ on strength of naturally aged seeds and growth of spinach. Biol. Trace Elem. Res. 104, 83-91. doi: 10.1385/BTER:104:1:083

Conflict of Interest Statement: The authors declare that the research was conducted in the absence of any commercial or financial relationships that could be construed as a potential conflict of interest.
The reviewer TJ declared a shared affiliation, though no other collaboration, with several of the authors SA, NJ, FA to the handling Editor, who ensured that the process nevertheless met the standards of a fair and objective review.

Copyright (C) 2016 Anwaar, Maqbool, Jabeen, Nazar, Abbas, Nawaz, Hussain and Hussain. This is an open-access article distributed under the terms of the Creative Commons Attribution License (CC BY). The use, distribution or reproduction in other forums is permitted, provided the original author(s) or licensor are credited and that the original publication in this journal is cited, in accordance with accepted academic practice. No use, distribution or reproduction is permitted which does not comply with these terms. 